\title{
CREATIVE THINKING SKILL AS AN IMPORTANT ASPECT IN DISRUPTIVE ERA
}

\section{Tri Yuda Bekti Pamungkas, Restu Peni Winahyu}

Universitas Sebelas Maret peniwinahyu@gmail.com

\section{Article History}

accepted 09/07/2018

approved 01/08/2018

published 17/09/2018

Keywords

Creative thinking skill, disruptive era, education.

\begin{abstract}
Disruptive era is a change of achievement towards a better innovation. Education is one of priority to prepare human resources to confront the disruptive era. As educational actor, student must have an important think one of that is creative thinking skill. Creative thinking skill is the basis for progress of quality and the mentality of the student. Creative thinking is the way to prepare disruptive era as the complexity of competitive. As the effective execution, creative thinking will increase the cognitive processes, held to depend on the strategies employed in process execution and the knowledge being used in problem solving. This paper uses the method of theory study. It so we make a result by some of the theory and made conclusion about the important creative thinking skill in disruptive era. Creative thinking skill is the one of the main stimulus to create gold era on 2045.
\end{abstract}

Social, Humanities, and Education Studies (SHEs): Conference Series https://jurnal.uns.ac.id/shes 


\section{PENDAHULUAN}

\section{A. Latar Belakang}

Dunia hari ini sedang menghadapi fenomena disruption (disrupsi). Disrupsi merupakan perubahan yang sangat mendasar sebagaimana telah terjadi di berbagai industri, seperti musik, surat-menyurat, media cetak, dan transportasi publik, seperti taksi (Mayling Oey Gardiner, dkk : 2017). Pernyataan tersebut didukung dengan adanya fakta-fakta di lapangan seperti lahirnya model bisnis baru dengan strategi lebih inovatif dan disruptif. Cakupan perubahannya luas mulai dari dunia bisnis, perbankan, transportasi, sosial masyarakat, hingga pendidikan. Era ini akan menuntut kita untuk berubah atau punah. Teknologi mendorong berbagai perubahan, tidak hanya dalam teknologi itu sendiri tetapi juga dalam kehidupan manusia, cara manusia berhubungan, cara kita ber organisasi. Teknologi digital sangat luas penerapannya, dan karenanya juga sangat luas dampaknya.

Sebagai bagian dari dunia, Indonesia harus mampu menyesuaikan diri dengan perubahan yang sedang terjadi di berbagai belahan dunia lain, terutama negara maju, yang memang banyak memengaruhi kehidupan manusia. IImuwan negara majulah yang banyak membuat berbagai terobosan dalam temuan berbentuk invensi dan inovasi dalam sains dan teknologi yang ketika diterapkan pada sarana dan prasarana yang kita gunakan sehari-hari dapat membawa dampak perubahan yang sangat mendasar. Perubahan mendasar dalam proses belajarmengajar telah dirasakan sebagai ancaman yang dapat memorak-porandakan kegiatan dan bahkan hingga keberadaan pendidikan.

Hal ini, sebagaimana telah diuraikan di atas, disebabkan oleh terjadinya perubahan mendasar dalam penyediaan jasa atau pelayanan khususnya dalam pendidikan yaitu karena dinamika perkembangan ilmu pengetahuan yang menghasilkan invensi dan inovasi dalam penerimaan, penggunaan dan pelaksanaan sains dan teknologi. Sementara itu, bangsa-bangsa dunia juga mengalami dinamika perubahan demografis dalam hubungan dengan struktur umur dan jenis kelamin secara umum, dan berbagai aspek kehidupan, termasuk pemerintahan dan pasar kerja, pasar pembeli dan penjual.

Sebagaimana dikatakan Presiden Republik Indonesia ke-7, Joko Widodo, untuk mampu menghadapi masa depan sebagai anggota bangsa-bangsa yang saling bekerja sama dan bersaing, keseluruhan sistem pendidikan, harus mengalami revolusi mental. Perubahan yang hanya dilakukan perlahan-lahan dan sedikit-sedikit dari pinggiran tidak akan dapat menempatkan pendidikan Indonesia di peta dunia secara berarti. Perubahan yang diperlukan sangat mendasar, bersifat pergeseran paradigma untuk melakukan lompatan jauh ke depan (leap frogging) dengan mengetahui sampai di mana kita berada.

Tidak diragukan lagi, disrupsi akan mendorong terjadinya digitalisasi sistem pendidikan di Indonesia. Munculnya inovasi aplikasi teknologi seperti Uber atau Gojek akan menginspirasi lahirnya aplikasi sejenis di bidang pendidikan. Misalnya MOOC, MOOC adalah sebuah model pembelajaran atau pembelajaran yang dapat dilakukan secara online untuk skala besar dan jumlah partisipan banyak tersebar dari beberapa wilayah yang berlainan dan berjauhan (Riche Chintya Johan:2013). Inovasi-inovasi tersebut bisa dijadikan sebagai upaya modernisasi pendidikan Indonesia agar tidak tertinggal dari negara-negara lain. Mengingat Indonesia tahun 2018 ini masih tertinggal dari Singapura, Malaysia, Brunei Darussalam dan Thailand di tingkat ASEAN yang dilansir Deutsche Welle.

Pada berbagai hal, inovasi - inovasi tersebut muncul didasarkan pada kreativitas dalam menyelesaikan permasalahan dan peka terhadap peluang. Creative problem-solving depends on the effective execution of a set of complex cognitive processes. Effective execution of these processes is, in turn, held to 
depend on the strategies employed in process execution and the knowledge being used in problem-solving (Mumford, D, Michael, dkk.: 30). Mumford menyatakan bahwa kemampuan berpikir kreatif dapat memecahkan permasalahan secara lebih efektif.

\section{B. Rumusan Masalah}

Rumusan masalah dalam makalah ini yaitu bagaimana unsur-unsur, upaya, dan manfaat creative thinking skill sebagai peranan penting mempersiapkan diri dalam era disrupsi.

\section{Tujuan}

Tujuannya yaitu untuk mengetahui kondisi yang ada di masyarakat dan mempersiapkan diri untuk menghadapi era disrupsi.

\section{HASIL DAN PEMBAHASAN}

Salah satu tujuan pendidikan adalah membuat anak berpikir kreatif baik untuk memecahkan masalah maupun untuk bisa berkomunikasi atau menyampaikan pemikiran mereka. Padahal, penerapan pembelajaran tidak mendorong siswa untuk berpikir kreatif. Dua faktor yang menyebabkan pemikiran kreatif tidak berkembang selama pendidikan adalah kurikulum yang pada umumnya dirancang dengan target material yang luas, sehingga pendidik lebih fokus menyelesaikan materi daripada pada metode pengajaran yang dapat meningkatkan kemampuan berpikir kreatif (Hasanah dan Surya, 2017). Kemampuan berpikir kreatif dalam era disrupsi menjadi hal yang krusial, apalagi dengan persaingan yang dikomputerisasi, masyarakat dituntut penuh untuk menguasai berbagai lini termasuk bagaimana bersaing dengan pemikiran yang kreatif. Hal ini tentu harus didukung dengan pembelajaran yang bisa dapat meningkatkan kreatifitas, hal ini dapat dimulai dengan kemampuan berpikir kreatif. Menurut Nuriana rachmani dewi dan masrukan (2018) berpikir kreatif merupakan aktivitas sesorang dalam menjawab suatu persoalan dengan beragam cara.

Adapun ciri-ciri kemampuan berpikir kreatif menurut Azhari (2013) antara lain meliputi: (1) Keterampilan berpikir lancar, (a) menghasilkan banyak gagasan/jawaban yang relevan (b) menghasilkan motivasi belajar (c) arus pemikiran lancar (2) Keterampilan berpikir lentur (fleksibel) (a) menghasilkan gagasan-gagasan yang seragam (b) mampu mengubah cara atau pendekatan (c) arah pemikiran yang berbeda (3) Keterampilan berpikir orisinil (a) memberikan jawaban yang tidak lazim (b) memberkan jawaban yang lain daripada yang lain (c) memberikan jawaban yang jarang diberikan kebanyakan orang (4) Keterampilan berpikir terperinci (elaborasi) (a) mengembangkan, menambah, memperkaya suatu gagasan (b) memperinci detaildetail (c) memperluas suatu gagasan.

Elly's Mersina Mursidik, dkk (2015) menyatakan kemampuan berpikir kreatif dapat diartikan sebagai kemampuan menciptakan sesuatu yang baru, atau kemampuan menempatkan dan mengombinasikan sejumlah objek secara berbeda yang berasal dari pemikiran manusia yang bersifat dapat dimengerti, berdaya guna, dan inovatif dengan berbagai macam faktor-faktor yang dapat mempengaruhi. la menjabarkan unsur-unsur berpikir kreatif seperti pada tabel di bawah ini:

\section{Berpikir Lancar}

\section{Pengertian}

- Mencetuskan banyak gagasan, jawaban, penyelesaian atau jawaban.

- Selalu memikirkan lebih dari satu jawaban.

\section{Perilaku Siswa}

- Mengajukan banyak pertanyaan.

- Menjawab dengan sejumlah jawaban jika ada pertanyaan.

- Mempunyai banyak gagasan mengenai suatu masalah.

- Lancar dalam menggunakan gagasan-gagasannya. 
- Bekerja lebih cepat dan melakukan lebih banyak daripada siswa lain.

- Dengan cepat melihat kesalahan dan kelemahan dari suatu objek atau situasi.

Berpikir Luwes
- Menghasilkan gagasan, jawaban
atau pertanyaan yang bervariasi.
- Dapat melihat suatu masalah dari
sudut pandang yang berbeda-
beda.
- Mencari banyak alternatif atau
arah yang berbeda-beda.
- Mampu mengubah cara
pendekatan atau pemikiran.

\section{Berpikir Orisinal}

- Mampu melahirkan ungkapan yang baru dan unik.

- Memikirkan cara-cara yang tak lazim untuk mengungkapkan diri.

- Mampu membuat kombinasikombinasi yang tak lazim dari bagian-bagian atau unsur-unsur.

- Memberikan aneka ragam penggunaan yang tak lazim terhadap suatu objek.

- Memberikan macam-macam penafsiran terhadap suatu gambar, cerita atau masalah.

- Menerapkan suatu konsep atau asas dengan cara yang berbedabeda.

- Memberikan pertimbangan atau mendiskusikan sesuatu selalu memiliki posisi yang berbeda atau bertentangan dengan mayoritas kelompok.

- Jika diberi suatu masalah biasanya memikirkan macam-macam cara yang berbeda-beda untuk menyelesaikannya.

- Menggolongkan hal-hal yang menurut pembagian atau kategori yang berbeda-beda.

- Mampu mengubah arah berpikir secara spontan.

- Memikirkan masalah-masalah atau hal yang tak pernah terpikirkan orang lain.

- Mempertanyakan cara-cara lama dan berusaha memikirkan caracara baru.

- Memilih a-simetri dalam membuat gambar atau desain.

- Mencari pendekatan baru dari stereotype.

- Setelah mendengar atau membaca gagasan, bekerja untuk mendapatkan penyelesaian yang baru.

Daniel Fasko (dalam Nehe dan dkk, 2017) menyatakan bahwa kemampuan berpikir kreatif matematis adalah kemampuan berpikir tingkat matematis itu termasuk dengan keaslian, elaborasi, kelenturan dan kefasihan. Karakteristik pemikiran kreatif yaitu orisinalitas, elaborasi, kelancaran dan kelenturan. Agar kreativitas anak bisa terwujud dibutuhkan mendorong individu (motivasi intrinsik) dan dorongan lingkungan (motivasi ekstrinsik).

Menurut Nurmasari dkk (2014) Berpikir kreatif dalam matematika dan dalam bidang lainnya merupakan bagian keterampilan hidup yang perlu dikembangkan terutama dalam menghadapi era informasi dan suasana bersaing semakin ketat. Individu yang diberi kesempatan berpikir kreatif akan tumbuh sehat dan mampu 
menghadapi tantangan. Sebaliknya, individu yang tidak diperkenankan berpikir kreatif akan menjadi frustrasi dan tidak puas. Pengembangan aktivitas kreatif tersebut adalah dengan melibatkan imajinasi, intuisi dan penemuandengan mengembangkan pemikiran divergen, orisinal, rasa ingin tahu, membuat prediksi dan dugaan serta mencoba-coba.

Berdasarkan pemaparan di atas dapat disimpulkan bahwa crative thinking skill adalah kemampuan menciptakan sesuatu yang baru melalui proses yang dilakukan saat memecahkan masalah dan dapat dianalisis melalui beberapa unsur, diantaranya adalah berpikir lancar, berpikir luwes atau fleksibel, berpikir orisinal dan elaborasi. Selanjutnya untuk menghadapi era disrupsi ini berpikir kreatif perlu dikembangkan. Karena kemampuan berrpikir kreatif merupakan modal awal bagi siswa untuk menghadapi era disrupsi. Sebagai contoh di era disrupsi teknologi sudah sangat maju, seperti pemanfaatan internet untuk kehidupan sehari-hari dalm bidang apapun. Maka siswa memerlukan creative thinking skill untuk memenuhi kebutuhannya dengan lebih mudah dan tepat. Nuriana dan Masrukan (2018) menyatakan bahwa berpikir kreatif perlu dikembangangkan terutama dalam menghadapi era informasi. Untuk mengembangkan kemampuan berpikir kreatif tersebut, pendidik harus menciptakan kondisi kelas yang dapat merangsang kepekaan siswa dalam belajar melalui pemberian tugas dengan memunculkan beberapa pertanyaan, seperti: "bagaimana jika", "apa yang keliru", "apa yang akan kamu lakukan", serta menyelesaikan soal dengan beragam cara (nuriana dan masrukan: 2018). Salah satu cara yang dapat digunakan sebagai upaya untuk mengembangkan kemampuan berpikir kreatif siswa ini adalah dengan cara memberikan soal-soal terbuka atau memberikan masalah pada saat pembelajaran. Soal-soal terbuka dan masalah ini kemudian dikerjakan siswa melalui diskusi kelompok, untuk kemudian hasilnya dipresentasikan di depan kelas. Dengan menggunakan soal-soal terbuka atau masalah di dalam pembelajaran, siswa dituntut untuk berpikir kreatif agar dapat menyelesaikannya. Selain itu dengan adanya diskusi kelompok akan membuat siswa yang kurang memahami materi bisa mendapatkan penjelasan dari siswa lain yang sudah memahami materi yang dipelajari.

\section{SIMPULAN}

Era disrupsi merupakan era dimana semua budaya lama digantikan dengan kebiasaan baru yang dianggap lebih praktis. Pemanfaatan teknologi dalam bidang apa pun saat ini tentu berdampak pada masyarakat. Salah satunya bidang pendidikan. Bahwa pendidikan juga harus berkembang lebih baik di era disrupsi ini. Kemampuan berpikir kreatif sangat diperlukan oleh masyarakat khususnya peserta didik di era disrupsi ini. Persaingan dunia yang semakin ketat menuntut seseorang harus berpikir keras untuk mempertahankan hidupnya. Melalui kemampuan berpikir kreatif, seseorang lebih mudah memecahkan masalah yang dihadapinya dengan tepat. Maka, kemampuan berpikir kreatif ini perlu dikembangkan sejak dini di pendidikan dasar.

\section{DAFTAR PUSTAKA 44718589}

Azhari. (2013). Peningkatan Kemampuan Berpikir Kreatif Matematik Siswa Melalui Pendekatan Konstruktivisme Di Kelas VII Sekolag Menengah Pertama (SMP) Negeri 2 Banyuasin III. Jurnal Pendidikan Matematika. Vol. 7, No.2.

Dewi, N. R. dan Masrukan (2018). Penigkatan Kemampuan Berpikir Kreatif Mahasiswa Program Magister. Jurnal UNNES.

Hasanah, M., dan Surya, E. 2017. Differences in the Abilities of Creative Thinking and Problem Solving of Students in Mathematics by Using Cooperative Learning and Learning of Problem Solving. International Journal of Sciences: Basic and Applied Research (IJSBAR)(2017) Volume 34, No 1.

Nehe, M., Surya, E., Syahputra, E. 2017. Creative Thinking Ability to Solving Equation and Nonequation of Linear Single Variable in VII Grade Junior High School. IJARIIE: Vol-3 Issue-2 2017. 
Mumford. D. Michael, dkk.(2012). Creative Thinking: Processes, Strategic, and Knowledge. The Journal of Creative Behavior, Vol. 46, Iss. 1, pp. 30-47 (C 2012 by the Creative Education Foundation

Mursidik, E. M., dkk. (2015). Kemampuan Berpikir Kreatif Dalam Memecahkan Masalah Matematika Open-Ended Ditinjau dari Tingkat Kemampuan Matematika Pada Siswa Sekolah Dasar. Journal Pedagogia ISSN 2089 -3833 Volume. 4, No. 1.

Nurmasari, N., Kusmayadi, A, T., Riyadi. (2014). Analisis Berpikir Kreatif Siswa Dalam Menyelesaikan Masalah Matematika Pada Materi Peluang Ditinjau Dari Gender Siswa Kelas XI IPA SMA Negeri 1 Kota BanjarBaru. Jurnal Elektronik Pembelajaran Matematika. Vol. 2, No. 4. 